\title{
MANAJEMEN USAHA DAN PENERAPAN DIGITAL MARKETING TANAMAN HIAS DI KOTA MATARAM
}

\section{THE BUSINESS MANAGEMENT AND DIGITAL MARKETING APPLICATION OF ORNAMENTAL PLANTS IN MATARAM CITY}

\author{
I Gusti Ayu Cynthia Mahacakri*; Abdullah Usman**; dan Wayan Suadnya ** \\ Program Studi Agribisnis Jurusan Sosial Ekonomi Pertanian Universitas Mataram \\ cynthiamahacakri@gmail.com
}

\begin{abstract}
ABSTRAK
Tujuan penelitian ini adalah untuk mengetahui bauran pemasaran digital yang dilakukan oleh pengusaha tanaman hias di Kota Mataram. Penelitian ini menggunakan metode deskriptif, dimana data dikumpulkan dengan teknik sensus. Unit analisisnya adalah pengusaha tanaman hias; Lokasi penelitian ini ditetapkan secara purposive sampling atas pertimbangan pengusaha tanaman hias paling banyak. Analisis yang digunakan adalah analisis deskriptif penerapan digital marketing dan analisis strategi digital marketing menggunakan bauran pemasaran digital 4C. Kesimpulannya adalah bahwa pada bauran pemasaran digital, pengusaha melakukan Co-Creation sesuai konsep pemasaran 4.0 pada pengembangan produk yakni melibatkan konsumen melalui Sosial Media dan Google Bisnis. Selanjutnya Communal activation dengan mencantumkan alamat usahanya di sosial media dan google bisnis untuk memudahkan dilacak dengan Google Maps. Promosi dengan istilah conversation yang sifatnya percakapan interaksi dua arah. Dimana konsumen bebas bertanya dan memberikan keluhan melalui sosial media mengenai harga dan kesepakatan pembelian. Bauran currency (padanan bauran price) menerapkan harga tetap untuk tanaman hias dipostingan sosial media. Pelanggan yang datang langsung ke kebun dapat menanyakan potongan harga tanaman hias yang diminati. Disarankan agar Pengusaha tanaman hias meningkatkan penjualan produknya melalui WhatsApp karena jangkauannya luas dan mudah; Untuk penelitian selanjutnya disarankan meneliti tentang pendapatan online karena penelitian ini terbatas hanya menghitung pendapatan usaha pada umumnya
\end{abstract}

\begin{abstract}
The objective of this study is: to find out the digital marketing mix carried out by ornamental plant entrepreneurs in Mataram City. This research uses a descriptive method. Data collection techniques using sensus. The unit of analysis in this study is the ornamental plant entrepreneur. The location of this study was determined purposivel, consideringthe number entrepreneurs. Data were analysed descriptively using the $4 \mathrm{C}$ digital marketing mix. The conclusions are (1) In the digital marketing mix the entrepreneur carries out Co-creation according to the marketing concept 4.0 on product development which involves consumers through Social Media and Google Business. Furthermore Comunal Activation by including the adress of his business on social media and Google Business to facilitate tracking with Google Maps. The fourth mix is currency, where the price is fixed for those who buy through social media. Alternatively, Customers can come directly to the garden asking discounts. The suggestions are (1) increase the sales through Whatsapp as it reaches consumers from various regions and provides many conveniences; (2 for further research it is advisable to research about online income because this research is limited to only calcualting operating income.
\end{abstract}

Keywords: digital marketing mix, google business, social media Kata kunci : bauran pemasaran digital, google bisnis, sosial media 


\section{PENDAHULUAN}

Nusa Tenggara Barat memiliki potensi tanaman hias karena secara geografis sangat mendukung dalam pengembangannya jika dikembangkan ke arah agribisnis dan Kota Mataram mempunyai potensi cukup baik sebagai sentra produksi tanaman hias. Besarnya produksi tanaman hias di Kota Mataram dikarenakan pemerintah Kota Mataram juga telah mencanangkan pemanfaatan Ruang Terbuka Hijau (RTH) yang akan mendorong pemanfaatan tanaman hias lebih luas lagi (Dinas Pertanian Kota Mataram, 2017). Pemasaran dimulai dengan pemenuhan kebutuhan yang kemudian tumbuh menjadi keinginan. Keinginan konsumen akan produk barang dan atau jasa menarik perhatian para pemasar sehingga mereka menggunakan daya upaya untuk mengingatkan, menginformasikan dan membujuk konsumen untuk melakukan pembelian (Manap, 2016). Perlu diketahui bahwa saat ini berbagai macam bisnis sudah semakin menyesuaikan dengan perkembangan zaman. Begitupula dengan teknologi informasi, penggunaan internet yang mampu mengakses berbagai macam informasi merupakan peluang bagi pengusaha tanaman hias untuk mengubah cara pemasarannya dari yang sebelumnya mengandalkan pemasaran konvensional dengan menambahkan digital marketing di dalam strateginya.

Ahyar Abduh selaku Walikota Mataram mengatakan posisi Usaha Mikro Kecil Menengah (UMKM) sebagai kelompok yang dikenal paling stabil, termasuk saat terjadi gejolak ekonomi. Sementara disisi lain, era digital sangat berpengaruh besar pada ranah bisnis di Nusa Tenggara Barat khususnya Kota Mataram yang mana perkembangan bisnis melalui dunia maya mengalami perkembangan yang pesat (https://www.suaralombok.com). Digital marketing adalah suatu upaya untuk memasarkan suatu produk atau jasa menggunakan media digital yang ada di internet untuk berinteraksi dengan konsumen. Masalah yang timbul adalah bagaimana menetapkan strategi pemasaran yang tepat agar produk tanaman hias semakin dikenal karena selama ini komunikasi dan proses transaksi yang terjalin masih menggunakan sistem konvensional yang mana dalam penjualannya responden menunggu pelanggan datang di kebun. Tidak dapat dipungkiri bahwa strategi pemasaran yang masih sangat optimal sampai dengan saat ini adalah pemasaran mulut ke mulut. Fakta yang ada di lapangan bahwa dalam kegiatan penjualan cukup banyak pengusaha tanaman hias yang sudah memanfaatkan smartphone. Berdasarkan uraian tersebut, maka perlu untuk dilakukan penelitian tentang "Manajemen Usaha dan Penerapan Digital Marketing Tanaman Hias di Kota Mataram". Tujuan penelitian ini adalah: untuk mengetahui bauran pemasaran digital yang dilakukan oleh pengusaha tanaman hias di Kota Mataram.

Dalam dunia modern saat ini, hampir mustahil meraih penjualan kepada sebanyak mungkin orang dengan cara menawarkan barang dari pintu ke pintu. Sebab, biaya operasi dari kegiatan tersebut terlalu besar. Pemasar tidak lagi bisa berkeliling kota berteriak-teriak. Sebab, tidak banyak lagi orang yang memiliki waktu luang untuk mendengarkan teriakan penjual. Pemasar juga tidak lagi memerlukan materi cetak yang secara terus-menerus dicetak dan dikirim ke segenap calon pembeli. Sebab, dikhawatirkan sebagian besarnya akan masuk ke dalam tong sampah (Hermawan, 2010). Perubahan marketing konvensional ke marketing digital ditandai dengan adanya perkembangan teknologi dan meningkatnya jumlah pengguna internet dari tahun ke tahun. Ketenaran sosial media dinilai sebagai trend baru di kalangan dunia marketing. Adanya perubahan teknologi yang dibarengi dengan perbedaan sifat dari konsumen menuntut sebuah brand / perusahaan harus lebih komunikatif dan relatif dalam menghadapi perubahan ini (Santoso, 2018). Lingkungan digital menghasilkan beragam data mulai dari data clickstream, ulasan dan penilaian pelanggan, $b l o g$, tag, dan data interaksi sosial terhadap respon pelanggan atas tindakan pemasaran dan informasi tentang kolaborator dan pesaing. Data ini sangat informatif bagi perusahaan untuk memahami perilaku pelanggan online, mengembangkan strategi pemasaran dan memastikan efektivitas tindakan dan taktiknya pada hasil pemasaran (Kannan, 2017). Dengan demikian, misi terpenting untuk pemasar di lingkungan digital adalah untuk mempromosikan dan memperdagangkan merek serta membangun kesetiaan pelanggan. Ini berarti tantangan baru untuk pemasaran digital yang sekarang harus lebih dari sebelumnya yaitu mampu memuaskan konsumen online (Minculete, 2018). Teknologi telah membuat proses produksi, pemasaran, distribusi dan bisnis secara keseluruhan menjadi lebih efektif dan efisien. Konektivitas yang dibangun pun memampukan banyak pelaku bisnis terhubung dengan akses-akses modal dan pasar yang baru. (Kotler, 2019).

Digital marketing adalah kegiatan promosi dan pencarian pasar melalui media digital secara online dengan memanfaatkan berbagai sarana misalnya jejaring sosial. Dunia maya kini tak lagi hanya mampu menghubungkan orang dengan perangkat namun juga orang dengan orang lain di seluruh dunia. Disatu sisi digital marketing memudahkan pebisnis memantau dan menyediakan segala kebutuhan konsumen, disisi lain konsumen juga bisa mencari dan mendapatkan informasi produk hanya dengan menjelajah dunia maya 
untuk memudahkan proses pencariannya (Purwana, 2017). Selain itu digital marketing bisa juga disebut sebagai pemasaran - $i$, web marketing, online marketing atau e-marketing atau e-commerce adalah pemasaran produk atau jasa melalui internet (Hermawan, 2012). Menurut Manap (2016) digital marketing atau transaksi perdagangan daring berbasis internet yang mana sebuah perusahaan kecil menggunakan media sosial marketing untuk promosi penjualan online untuk menemukan dan memelihara hubungan yang menguntungkan. Salah satunya adalah $E$-commerce yang merupakan model bisnis dalam penjualan produk dengan tiga kemungkinan: (1) B2C dimana produk dijual langsung ke konsumen. (2) B2B dimana perusahaan menjual produk ke perusahaan lain (antar perusahaan atau antar bisnis) dan (3) C2C konsumen menjual produk ke konsumen lain.

Menurut Manap (2016) Keunggulan digital marketing yaitu: (1) Biaya Rendah. Semakin cerdas marketer membangun strategi dan cara mengeksekusinya efektif maka investasinya semakin murah. ROI nya semakin lebih tinggi. Rasio biaya terhadap jangkauan target pelanggan, perusahaan dapat menjangkau khalayak luas dengan sebagian kecil dari keseluruhan anggaran periklanan, bisnis memiliki keuntungan untuk menarik konsumen dengan cepat. (2) Mempertahankan pelanggan. Masalah terpenting dalam pemanfaatan media online ini adalah pertama bagaimana kita mendapatkan traffic (pengunjung) sebanyak mungkin ke situs web kita ataupun sosial media kita. Digital marketing akan berhasil $100 \%$ jika pengunjung atau pembeli terus menerus melakukan pembelian di situs perusahaan. (3) Customer partnership. Dalam jejaring sosial para pengguna menciptakan komunitas atas dasar semangat dan kepentingan yang sama (segmentasi) dari semua lapisan masyarakat di seluruh belahan dunia ini untuk berinteraksi satu sama lain.

Internet menjdi sebuah media ampuh bagi pelaku bisnis untuk memasarkan, mengomersilkan, dan mempromosikan setiap produk dimana terdapat peluang untuk memasarkan produk serta layanan kepada para pengguna internet. Hal inilah yang menjadi pemicu pelaku bisnis online untuk terus mengembangkan bisnisnya pada media internet. Disamping itu dengan menempatkan usaha dipencarian di google memungkinkan produk kita memiliki nama di mata konsumen. (Kenrianto, 2017). Bagi seorang pelaku usaha yang professional dengan membuat Facebook Page dan Instagram maka kita senantiasa memberikan informasi produk untuk mendapatkan kepercayaan dari konsumen yang memang membutuhkan produk/jasa yang ditawarkan (Sutanto, 2017). Sosial media yang digunakan oleh pengusaha tanaman hias juga terdiri dari Whatsapp, Email, dan Youtube yang mana masing-masing mempunyai potensi untuk meraih target pasar dan membantu proses penjualan di era yang serba digital ini.

Strategi digital marketing. Co-creation Dalam buku Marketing 4.0 Bergerak dari Tradisional Ke Digital (Kotler, 2019) suatu produk menjadi co-creation yaitu pelanggan ikut terlibat untuk menciptakan produk perusahaan yang lebih dinamis bersifat interaktif dan berasal dari multisumber. Perusahaan harus cepat tanggap apa yang diinginkan pelanggannya baik secara komunitas maupun personal. Karena sudah adanya kedekatan perusahaan dengan konsumen dengan setaranya pola komunikasi, maka akan mempermudah perusahaan membuat produk yang benar-benar sesuai bahkan personal dengan pelanggannya. Currency Harga maknanya cenderung tetap, sementara currency lebih fleksibel. Produk atau co-creation yang telah dibuat nantinya tidak mempunyai nilai harga yang tetap. Untuk produk yang sama, nilainya dapat naik, dapat pula turun tergantung pada berbagai faktor terkait seperti waktu maupun biaya-biaya pada proses. Profitabilitas perusahaan disesuaikan dengan penetapan harga yang dibebankan secara dinamis kepada para pelanggan mencakup jarak lokasi toko, pola pembelian historis, dan aspek profil pelanggan lain Communal Activation Mengaktifkan sebuah komunitas melalui para pemimpin atau aktivis komunitas karena mampu memasarkan produk atau co-creation kepada para anggota komunitasnya. Mengelola para aktivis komunitas bagi produsen akan lebih efektif dan efisien daripada saluran distribusi tradisional. Bagi pelanggan, menggunakan pihak ketiga untuk mendistribusikan suatu barang dianggap lebih praktis. Conversation Conversation berarti diskusi atau interaksi antara semua pihak yang kedudukannya setara. Dari sisi penerimaan pelanggan terhadap informasi yang disampaikan perusahaan, conversation akan dianggap lebih dipercaya ketimbang promosi. Dari sisi anggaran, conversation merupakan praktik low-budget-high-impact marketing dengan biaya pemasaran yang murah.

\section{METODOLOGI PENELITIAN}

Penelitian ini menggunakan metode deskriptif yaitu suatu metode dalam meneliti kelompok manusia, objek, suatu set kondisi, sistem pemikiran, ataupun suatu kelas peristiwa pada masa yang akan datang. Tujuannya adalah untuk membuat deskripsi, gambaran atau lukisan secara sistematis, faktual dan akurat mengenai fakta-fakta, sifat-sifat serta hubungan antara fenomena yang diselidiki (Nazir, 2009). Teknik pengumpulan data yang digunakan dalam penelitian ini adalah teknik survey yaitu dengan 
mengumpulkan data dari sejumlah unit atau individu dalam waktu yang bersamaan dengan mengadakan wawancara langsung disertai dengan daftar pertanyaan yang disiapkan sebelumnya (Nazir, 2009). Unit analisis dalam penelitian ini adalah pengusaha tanaman hias di Kota Mataram. Jenis data dalam penelitian ini adalah data kuantitatif dan data kualitatif, sedangkan sumber data dalam penelitian ini yaitu: data primer dan data sekunder. Kota Mataram terdiri dari 6 kecamatan yaitu Kecamatan Ampenan, Sekarbela, Mataram, Sandubaya, Selaparang dan Cakranegara. Dalam penelitian ini ditetapkan 2 kecamatan yaitu Kecamatan Ampenan dan Kecamatan Selaparang secara purposive sampling atas pertimbangan bahwa pada kecamatan tersebut terdapat pengusaha tanaman hias paling banyak. Jumlah responden ditentukan secara sensus yaitu sebanyak 18 responden. Selanjutnya, pemilihan responden ditentukan secara accidental sampling dengan teknik wawancara langsung dengan responden. Analisis yang digunakan dalam penelitian ini adalah: analisis deskriptif penerapan digital marketing dan strategi digital marketing dengan bauran pemasaran $4 \mathrm{C}$ yang orientasinya adalah Customer (pelanggan).

Analisis Data untuk mengetahui Penerapan digital marketing pada usaha tanaman hias di analisis secara deskriptif yaitu dengan menganalisis sosial media yang terdiri dari (WhatsApp, Facebook, Email, Instagram, Youtube) dan Google Bisnis yang digunakan oleh responden dan manfaat serta kerugian dari pemasaran offline-online. Kriteria yang digunakan dalam mengkaji Strategi Digital Marketing disajikan pada Tabel 1.

Tabel 1. Kriteria Pelaksanaan Manajemen Pemasaran Berdasarkan Bauran Pemasaran 4C

\begin{tabular}{|c|c|c|c|c|}
\hline No & $\begin{array}{l}\text { Produk } \\
\text { creation })\end{array}$ & $\begin{array}{l}\text { Distribusi } \\
\text { (Communal } \\
\text { Activation) }\end{array}$ & Promosi (Conversation) & Harga (Currency) \\
\hline 1 & $\begin{array}{l}\text { Penggunaan } \\
\text { sosial media }\end{array}$ & $\begin{array}{l}\text { Layanan jasa } \\
\text { pesan antar } \\
\text { online }\end{array}$ & $\begin{array}{l}\text { Percakapan interaktif } \\
\text { dengan pelanggan di } \\
\text { sosial media }\end{array}$ & $\begin{array}{l}\text { Pencantuman harga di } \\
\text { sosial media }\end{array}$ \\
\hline 2 & $\begin{array}{l}\text { Penggunaan } \\
\text { Google Bisnis }\end{array}$ & 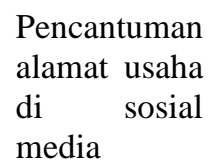 & & $\begin{array}{lrr}\begin{array}{l}\text { Potongan } \\
\text { diberlakukan }\end{array} & \text { di } & \text { sosial } \\
\text { media } & & \end{array}$ \\
\hline 3 & $\begin{array}{l}\text { Mengupload } \\
\text { foto aktivitas } \\
\text { usaha dan } \\
\text { produk }\end{array}$ & & & \\
\hline
\end{tabular}

\section{HASIL DAN PEMBAHASAN}

Digital marketing adalah sebuah usaha untuk memasarkan produk dan jasa melalui media digital yang ada di internet untuk menjangkau konsumen. Disamping itu melayani permintaan konsumen dapat dilakukan dengan mudah dan cepat hanya melalui layar smartphone. Pemasaran digital erat kaitannya dengan pemasaran konvensional yang bertujuan dalam pencapaian target konsumen serta produk yang akan dipasarkan.

Tabel 2. Media Digital yang digunakan Pengusaha Tanaman Hias di Kota Mataram

\begin{tabular}{llrr}
\hline \multirow{2}{*}{ No } & \multicolumn{1}{c}{$\begin{array}{c}\text { Karakteristik Media Digital yang } \\
\text { Digunakan }\end{array}$} & $\begin{array}{c}\text { Jumlah } \\
\text { Responden }=18\end{array}$ & Persentase \\
\hline 1 & WA (Whatsapp) & 17 & $94,44 \%$ \\
2 & FB (Facebook) & 8 & $44,44 \%$ \\
3 & IG (Instagram) & 4 & $22,22 \%$ \\
4 & Google Bisnis & 4 & $22,22 \%$ \\
5 & Email & 3 & $16,67 \%$ \\
6 & Youtube & 1 & $5,56 \%$ \\
\hline
\end{tabular}

Sumber: Data Primer Diolah, 2019 
Dari 18 responden yang dijadikan sampel untuk penelitian ada satu responden yang tidak bersedia memberikan informasi media digital apa saja yang digunakan dalam kegiatan pemasarannya. Rata-rata pengusaha tanaman hias di Kota Mataram menggunakan sosial media terdiri dari What's app, Facebook , Instagram Email, Youtube dan Google Bisnis yang bersifat gratis. Sebanyak 17 responden $(94,44 \%)$ tanaman hias menggunakan instant messenger what's app untuk memudahkan berkomunikasi dengan pelanggan sekaligus melakukan penawaran produk. Selanjutnya Facebook 8 responden (44,44\%), Instagram dan Google Bisnis sebanyak 4 responden (22,22\%). Sebanyak 3 responden menggunakan Email $(16,67 \%)$. Dan sisanya menggunakan Youtube hanya 1 responden $(5,56 \%)$.

What'sApp. Setiap konsumen yang ingin melakukan pembelian tanaman hias dapat menghubungi pengusaha melalui aplikasi perpesanan instan (Instant messenger) What's App. Dikarenakan what's app memiliki fitur yang canggih yang memudahkan komunikasi secara dua arah. Kemudahan yang dirasakan oleh pengusaha diantaranya adalah mengirimkan foto produk tanaman hias, dapat mengambil gambar lalu mengirimkan bukti transfer via rekening, melalukan panggilan telepon, mengirim pesan suara kepada konsumen dan melakukan panggilan video. Disamping itu pengusaha dapat menangani keluhan konsumen terkait perawatan tanaman hias yang sakit dan rusak pada saat pengiriman. Sebanyak 17 responden (94,44\% ) mengatakan dengan adanya what's app arah pembicaraan menjadi lebih jelas dibandingkan SMS (Short Messages System) yang menguras banyak pulsa apalagi jika nomor konsumen yang hendak dituju berbeda saluran operator. Berdasarkan tabel 2, sebanyak 5 (lima) responden paling banyak menggunakan Digital Marketing terutama layanan Whatsapp yaitu: Anugrah Garden +62 817-5741-916, Putu Garden +62 819-3676-2500, Didit garden +62 853-3302-9218, Kameda Nursery 62 852-3871-9195, dan Taman Kartika Ayu +62 812-3603-9644.

Facebook. Facebook merupakan layanan aplikasi yang ada internet dan digunakan untuk melakukan penelusuran produk serta sarana promosi. Saat ini facebook masih diminati oleh berbagai kalangan karena penggunaannya yang mudah. Facebook merupakan media digital yang bagus untuk kalangan pebisnis karena bisa saling berbagi tips dan artikel bermanfaat seputar budidaya tanaman hias. Karena facebook adalah tempat menjalin interaksi sebaik mungkin dengan teman dan khalayak ramai. Menyukai postingan dan saling mengirim pesan di messenger.Sehingga akan mudah menambah pertemanan yang sesuai target jika sudah kenal dan timbul kepercayaan satu sama lain maka akan mudah untuk berjualan. Percaya dalam arti sudah dikenal dan juga pengusaha dianggap punya potensi atas produk yang dijual.

Instagram. Banyaknya pebisnis yang menggunakan Instagram dimanfaatkan juga oleh pengusaha tanaman hias dalam memperkenalkan produk, sarana produksi pertanian serta mempromosikan jasa pembuatan taman melalui Instagram. Media sosial dengan fiturnya yang menarik dimanfaaatkan sebagai media promosi online barang/jasa melalui foto.

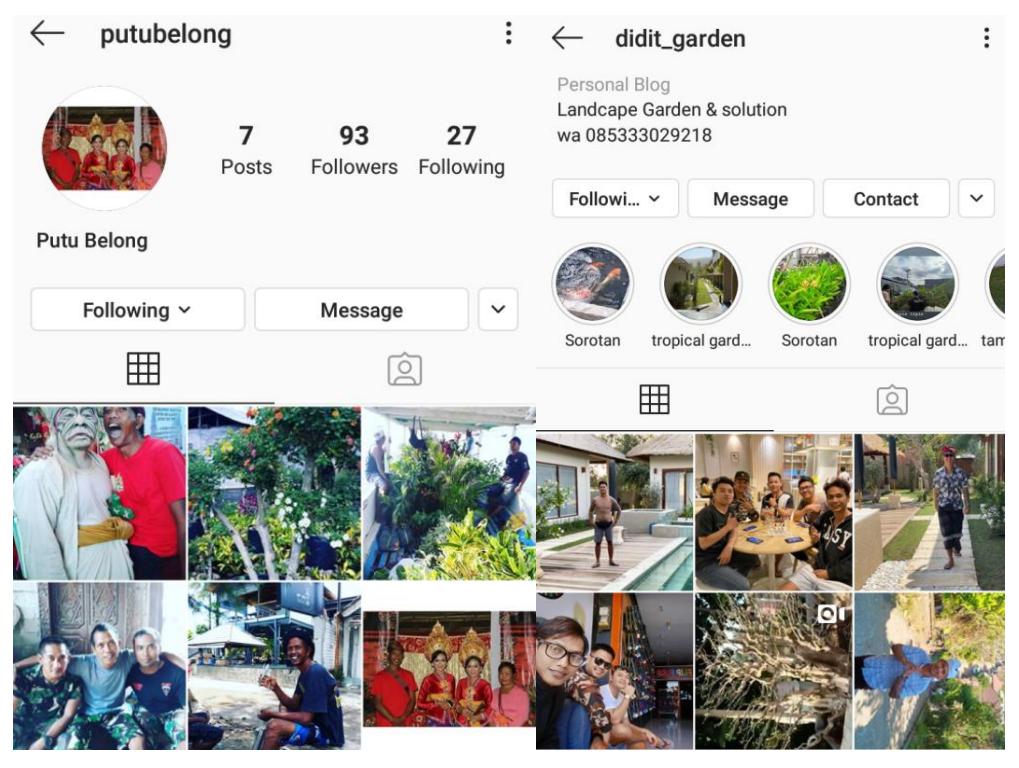

Mahacakri, I.G.A.C., Usman, A. dan Suadnya, W. 

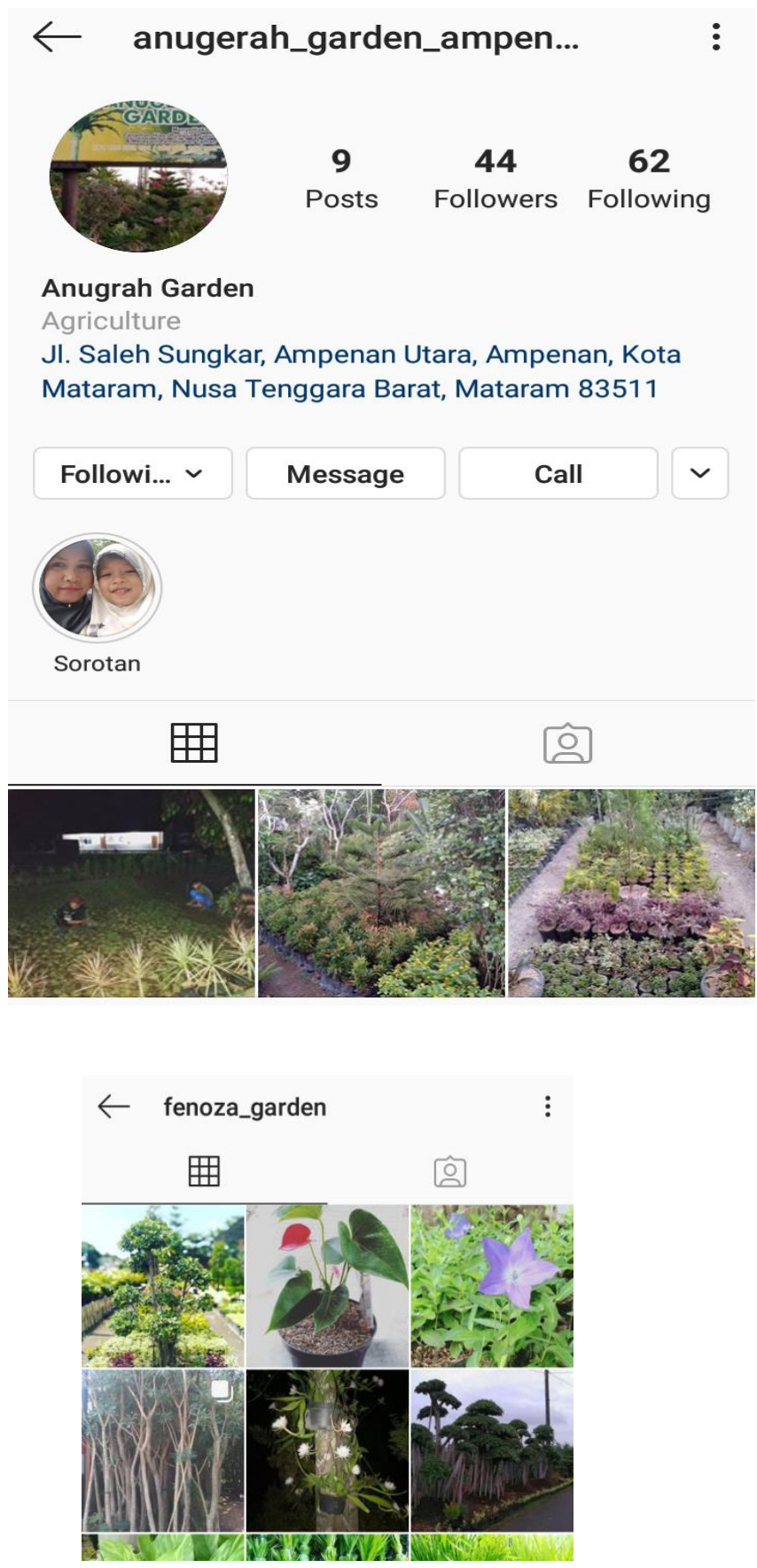

Gambar 1. (a,b,c,d,) Instagram Responden Pengusaha Tanaman Hias di Kota Mataram

Google Bisnis. Selain what's App , Anugrah Garden, Putu Garden, Kameda Nursery, dan Taman Kartika Ayu menggunakan Google Bisnis dalam aktivitas pemasaran digital. Berbeda dengan What's App yang fokus utama adalah komunikasi dengan pelanggan. Google my business adalah sebuah platform yang dikembangkan oleh Google dimana kita bisa memanfaatkannya untuk memberikan informasi yang cukup detail. Bagi pelaku bisnis ini fitur ini memberikan manfaat untuk membantu strategi pemasaran di dunia digital. Manfaat Google bisnis diantaranya: (1) Ketika sudah terdaftar di Google bisnis usaha apapun akan dipromosikan oleh Google Map. Ini memudahkan konsumen. (2) Mendapatkan review atau ulasan dari pelanggan. Tidak dapat dipungkiri bahwasannya sampai dengan saat ini satu-satunya perangkat yang bisa 
memberikan penilaian. Semakin banyak review (ulasan) maka semakin banyak konsumen yang percaya produk kita. (3) Google Bisnis dapat meningkatkan kunjungan ke toko kita atau ke tempat bisnis kita berada. Sangat bagus untuk pencarian lokal ketika mengetikkan kata kunci di Google maka yang akan dimunculkan adalah lokasi usaha yang berada di satu kota atau satu provinsi dengan kita. Contohnya yaitu : Garden di Ampenan.

Konsumen dapat memberikan penilaiannya baik itu ulasan positif dan ulasan negatif di Google berupa bintang 1 (paling rendah) hingga bintang 5 (tertinggi). Tentunya penilaian bintang ini akan menjadi bahan evaluasi untuk pengusaha dalam meningkatkan kinerja usaha dan produk tanaman hias yang dihasilkan. Di era digital seperti sekarang kecil kemungkinan perusahaan tidak melibatkan pelanggan disetiap kegiatan pemasarannya. Adapun di dalam penelitian ini Anugrah Garden memiliki 4 ulasan dari pelanggan sama halnya dengan Putu Garden, Kameda Nursery memiliki 1 ulasan, dan Taman Kartika Ayu belum memiliki ulasan dari pelanggan.

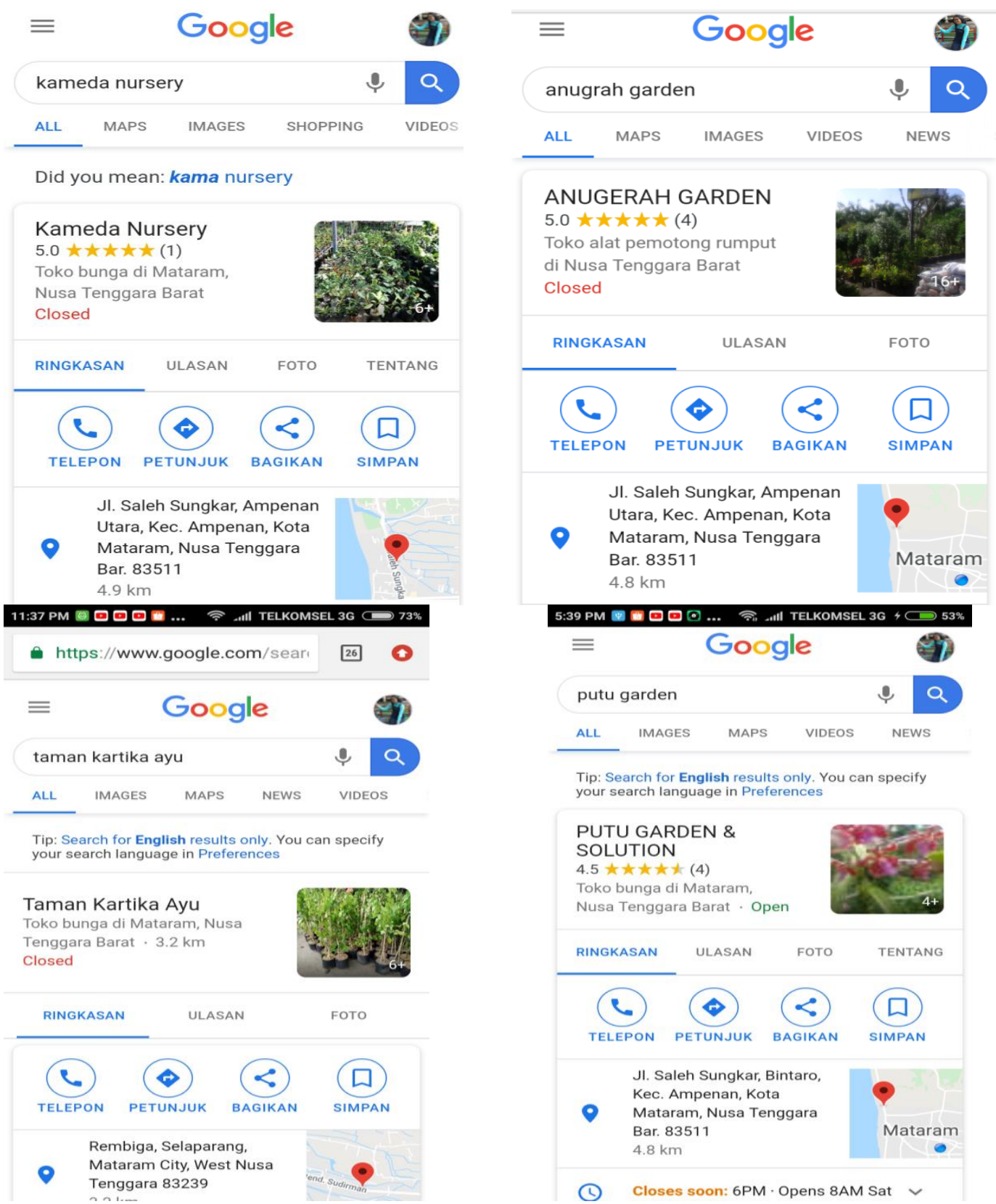

Gambar 2. Google Bisnis Yang Digunakan Oleh Pengusaha Tanaman Hias 


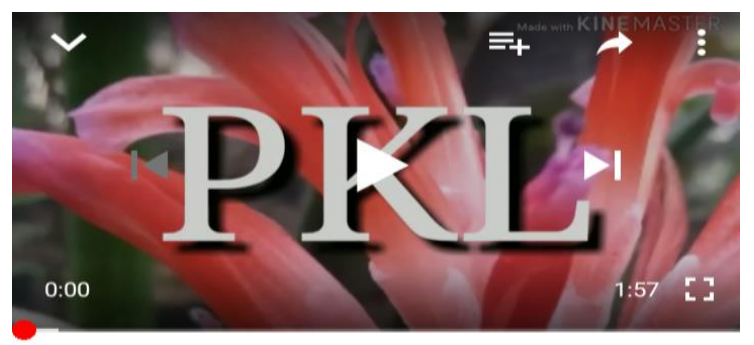

Email. Email merupakan sarana berkomunikasi untuk berkomunikasi dengan pelanggan yang sifatnya pribadi adapun responden yang menggunakan email diantaranya Didit garden dengan email putudiditpratama@gmail.com, Taman Kartika Ayu dengan email verdiansyah808@gmail.com. Selanjutnya Edelweis garden dengan email edelweissgarden@gmail.com.

Youtube. Youtube juga digunakan oleh

Belajar bertanam yang baik hanya ada Anugrah Garden dengan link di ANUGRAH GARDEN , PKLkok makan ... 5 views
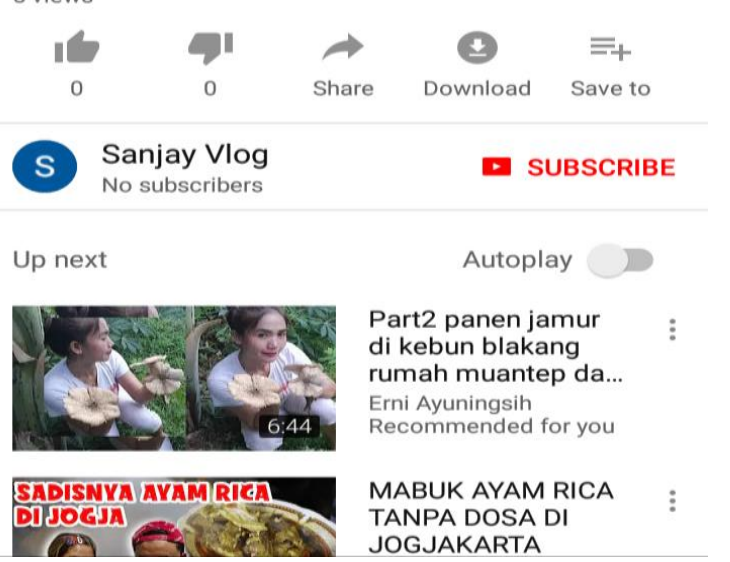
https://youtu.be/B2un7S420sY. dimana akun ini dibuat oleh mahasiswa Pertanian Fakultas Pertanian Universitas Mataram yang mengikuti Praktek Kerja Lapangan (PKL) dengan tujuan untuk berbagi video seputar pengalaman, informasi selama mengikuti kegiatan tersebut. Secara tidak langsung mahasiwa tersebut sudah ikut mempromosikan dan mempublikasikan Anugrah Garden.

Gambar 3. Youtube sebagai media promosi kegiatan PKL

Tabel 3. Manfaat dari Penggunaan Sosial media dan Google Bisnis Pengusaha Tanaman Hias di Kota Mataram

\begin{tabular}{llrr}
\hline No & \multicolumn{1}{c}{ Manfaat } & Jumlah & $\%$ \\
\hline 1 & Komunikasi langsung dengan konsumen melalui media sosial & 17 & $94,44 \%$ \\
\hline 2 & $\begin{array}{l}\text { Komunikasi langsung dengan distributor (petani di Malang) dan agen (di } \\
\text { Bayumulek) } \text { untuk memproleh bibit }\end{array}$ & 17 & $94,44 \%$ \\
\hline 3 & Mempromosikan produk tanaman hias yang dijual & 17 & $94,44 \%$ \\
\hline 4 & Melakukan kesepakatan pembelian dan penjualan & 17 & $94,44 \%$ \\
\hline 5 & Menampilkan photo produk hasil budidaya tanaman hias & 17 & $94,44 \%$ \\
\hline 6 & Mengetahui permintaan pasar dan konsumen & 15 & $83,33 \%$ \\
\hline 7 & Mendapatkan pelanggan baru & 14 & $77,78 \%$ \\
\hline 8 & Menangani keluhan konsumen & 11 & $61,11 \%$ \\
\hline 9 & Forum diskusi sesama pecinta tanaman hias & 10 & $55,56 \%$ \\
\hline 10 & Hemat karena tidak perlu mengeluarkan biaya cetak kartu nama & 7 & $38,89 \%$ \\
\hline 11 & Memudahkan pencarian lokasi usaha di Google Maps & 4 & $22,22 \%$ \\
\hline 12 & Konsumen dapat menilai kualitas produk menggunakan sistem bintang di & 4 & $22,22 \%$ \\
\hline
\end{tabular}

Sumber: Data Primer Diolah, 2019

Berdasarkan hasil wawancara pengusaha tanaman hias merasakan banyak manfaat yang diperoleh dengan menggunakan sosial media dan google bisnis sebagai sarana pemasaran tanaman hias. Sosial media dianggap penting karena pengusaha bisa melakukan komunikasi langsung dengan konsumen, agen dan 
distributor untuk memperoleh bibit, mengetahui permintaan pasar dan konsumen sehingga dapat meningkatkan penjualan. Media sosial adalah sarana bagi individu atau kelompok untuk saling bertukar dan berbagi informasi melalui teknologi internet. Dengan adanya forum diskusi di grup WhatsApp pengusaha dapat mengedukasi pasar atau melakukan penjualan. Hal lain yang dirasakan adalah sosial media hemat sehingga tidak perlu mengeluarkan biaya promosi berupa cetak kartu nama yang membutuhkan banyak biaya. Dengan mendaftarkan Google Bisnis maka bisnis tanaman hias yang dikelola akan muncul di pencarian Google maupun di Google Maps. Disamping itu Google Bisnis sifatnya publik dan objektif dalam memperlihatkan ulasan pelanggan (reviews) baik itu wisatawan lokal maupun asing yang sudah pernah berkunjung ke lokasi usaha untuk membeli bunga yang dijual oleh pengusaha tanaman hias. Adapun kekurangan media sosial yang dirasakan oleh pengusaha yaitu banyaknya informasi terkait dengan hoax dan sebagainya yang tidak relevan dengan usaha tanaman hias khususnya di Grup WhatsApp.

Bauran Pemasaran Digital Tanaman Hias di Kota Mataram. Sebanyak 4 responden $(22,22 \%)$ melakukan Co-Creation sesuai konsep pemasaran 4.0 pada produk tanaman hiasnya. Pada pengembangan produk pengusaha tanaman hias melibatkan konsumen melalui interaksi sosial media dan Google Bisnis. Konsumen dapat mencari alamat usaha di laman pencarian google lalu memberikan (review) ulasan bintang baik itu bintang 1 sampai bintang 5 dan bila sudah pernah berkunjung dan membeli produk Di sosial media ketika pengusaha mengupload foto kegiatan atau produk konsumen bisa turut serta memberikan tanggapannya melalui kolom komentar dan like. Hal ini menjadi realita dari Co-creation dimana perusahaan yang bergerak di bidang agribisnis tanaman hias dapat memanfaatkan bisnis digital dalam melakukan pengembangan produknya di internet secara lebih terukur dengan pola komunikasi yang dinamis melibatkan konsumen.

Bentuk kedua dalam bauran pemasaran digital adalah Place. Pada konsep pemasaran digital 4.0 menyebutkan bahwa pada pemasaran digital akan lebih menguntungkan jika memanfaatkan Communal activation dimana jalur distribusi bisa menggunakan pihak ketiga untuk mendistribusikan suatu barang dianggap lebih praktis. Sebanyak 2 responden $(11,11 \%)$ mencantumkan alamat usaha nya di sosial media Instagram dan Google Bisnis sebanyak 4 responden (22,22\%) untuk memudahkan dilacak dengan Google Maps. Dan 1 responden $(5,56 \%)$ yaitu Anugrah Garden pernah memanfaatkan jasa Go-Jek untuk mengantarkan pesanan bunga ke pelanggan berlokasi di Pagutan dengan ongkos kirim 10 ribu. Selain memiliki toko online, pengusaha juga memiliki toko offline dimana konsumen bisa mendatangi langsung lokasi usaha di Ampenan dan Selaparang untuk melakukan transaksi dan pembayarannya dilakukan ditempat.

Bauran Pemasaran Digital berikutnya adalah promosi yang juga diterapkan oleh Pengusaha Tanaman Hias sesuai dengan konsep pemasaran digital 4.0 dimana bentuk promosi tidak lagi berupa komunikasi satu arah (face to face) yang mengharuskan untuk bertemu langsung dengan konsumen tapi sudah menjadi Conversation yang sifatnya percakapan interaksi dua arah melalui layar smartphone dimana konsumen bebas bertanya atau memberikan keluhan melalui via Whatsapp, Facebook, email dan Instagram mengenai harga produk tanaman hias sekaligus melakukan kesepakatan penjualan dan pembelian. Bentuk keempat dalam bauran pemasaran digital berikutnya adalah price yang juga diterapkan oleh beberapa pengusaha tanaman hias sesuai dengan konsep pemasaran digital 4.0 dimana bentuk harga sudah menjadi Currency dimana penetapan harganya tetap untuk harga tanaman hias di kebun maupun dipostingan sosial media. Pelanggan juga bisa datang ke kebun menanyakan potongan harga tanaman hias yang diminati.

\section{KESIMPULAN DAN SARAN}

Berdasarkan hasil penelitian dapat disimpulkan bahwa pada bauran pemasaran digital pengusaha melakukan Co-Creation sesuai konsep pemasaran 4.0 pada pengembangan produk yakni melibatkan konsumen melalui Google Bisnis . Konsumen dapat mencari alamat usaha di laman pencarian google lalu memberikan ulasan. Selanjutnya Communal activation dengan mencantumkan alamat usaha nya di sosial media dan google bisnis untuk memudahkan dilacak dengan Google maps. Dan 1 responden memanfaatkan jasa Go-Jek untuk mengantarkan pesanan bunga ke pelanggan berlokasi di Pagutan. Promosi dengan istilah Conversation yang sifatnya percakapan interaksi dua arah. Dimana konsumen bebas bertanya dan memberikan keluhan melalui via sosial media mengenai harga dan melakukan kesepakatan pembelian. Bentuk keempat dalam bauran pemasaran digital adalah price dengan istilah Currency dimana penetapan harganya tetap untuk harga tanaman hias di kebun maupun dipostingan sosial media. Pelanggan juga bisa datang langsung ke kebun menanyakan potongan harga tanaman hias yang diminati. 
Disarankan kepada Pengusaha tanaman hias agar meningkatkan penjualan produknya melalui whatsapp untuk berbisnis karena WhatsApp menjangkau konsumen dari berbagai wilayah dan memberi banyak kemudahan; Untuk penelitian selanjutnya disarankan meneliti tentang pendapatan online karena penelitian ini terbatas hanya menghitung pendapatan usaha pada umumnya.

\section{DAFTAR PUSTAKA}

Dinas Pertanian Propinsi NTB. 2017. Statistik Produksi Tanaman Hortikultura. Mataram.

Hermawan, A., 2012. Komunikasi Pemasaran. Penerbit Erlangga. Jakarta.

Kannan, P.K., Hongshuang A.L. 2017. Digital Marketing: A Framework, Review, and Research. International Journal of Research in Marketing 34: 38-39. [19/08/2019].

Kenrianto. 2017. Bisnis Online Revolution. PT Gramedia Pustaka Utama. Jakarta

Kotler et al,. 2019. Marketing 4.O.Bergerak dari Tradisional ke Digital. PT Gramedia Pustaka Utama. Jakarta.

Manap, H.A. 2016. Revolusi Manajemen Pemasaran. Mitra Wacana Media. Jakarta.

Minculete, G., Olar, P. 2018. Approaches To the Modern Concept of Digital Marketing. International Conference Knowledge - BASED ORGANIZATION 24: 63-69. [19/08/2019].

Nazir M. 2009. Metode Penelitian. Ghalia Indonesia. Jakarta

Purwana, et al., 2017. Pemanfaatan Digital Marketing Bagi Usaha Mikro, Kecil dan Menengah (UMKM) di Kelurahan Malaka Sari, Duren Sawit. Jurnal Pemberdayaan Masyarakat Madani (JPMM) EISSN: 2580- 4332 Vol 1 No 1. [19/08/2019].

Redaksi Suara Lombok. 2019. http://www.suaralombok.com/2019/06/gelar-digital-marketing-walikota_26.html?m=0 Diakses pada tanggal [29/07/2019].

Santoso, P.Y. 2018. Transformasi Integrated Marketing Communication di Era Digital. Jurnal Pustaka Komunikasi Online ISSN: 2614- 8498 Vol 1 No 2. [24/07/2019].

Sutanto, G.M. 2017 The Power of Digital Marketing. PT Elex Media Komputindo. Jakarta. 